\title{
Restaurant Icon Frank DePasquale Shares Recipe for Success
}

\author{
Kimberly Eddleston (Northeastern University)
}

\section{KEYWORDS: Accommodation \& Food Services, \\ Entrepreneurship, Leadership.}

Boston restauranteur Frank DePasquale has built his empire with this recipe: Learn as much as you can from other entrepreneurs and those who work for you. Listen to your customers. Hug your employees. Build a team of people who love the business as much as you do. In this interview with Northeastern University Professor Kimberly Eddleston, DePasquale talks about how he opened his first small restaurant and subsequently built a collection of standout eateries in Boston's picturesque, historic North End, a mecca for Italian food fans. 